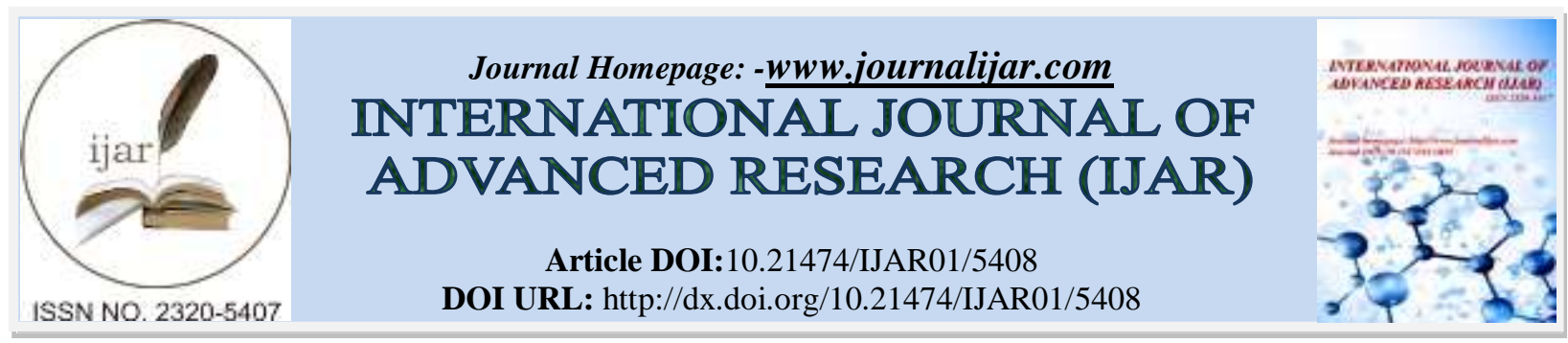

RESEARCH ARTICLE

\title{
BIODIVERSITY, HABITAT AND MORPHOLOGY OF MUSHROOM OF DIFFERENT FOREST REGIONS OF BANGLADESH.
}

\author{
M. H. Rashid, K. Akhter, M. S. M. Chowdhury and *F. M. Aminuzzaman. \\ Department of Plant Pathology, Faculty of Agriculture, Sher-e-Bangla Agricultural University, Sher-e-Bangla \\ Nagar, Dhaka-1207, Bangladesh.
}

\section{Manuscript Info}

Manuscript History

Received: 12 July 2017

Final Accepted: 14 August 2017

Published: September 2017

Key words:-

Deciduous forest; leaved forest, biodiversity; mushroom, Bangladesh.

\begin{abstract}
A survey was conducted to study the biodiversity, habitat and morphology of mushroom grown in leaved, deciduous and mixed forest of Bangladesh. A total of 117 samples were collected from nine selected districts of Bangladesh viz. Barisal, Borguna, Patuakhali, Perojpur, Jhalokathi, Bandorban, Dhaka, Gazipur and Tangail. About 12 different species were found under 10 families viz. Amanitaceae (Amanita bisporigera), Pyronemataceae (Aleuria aurantia), Boletaceae (Boletus subvelutipes), Agaricaceae (Agaricus sp.), Tricholomataceae (Callistosporium sp.), Marasmiaceae (Gymnopus sp.), Cortinariaceae (Cortinarius corrugatus), Mycenaceae (Mycena epipterygia), Entolomataceae (Nolanea strictia), Ganodermataceae (Ganoderma lucidum, Ganoderma applanatum, Ganoderma tsuage).The predominant genera were Amanita, Aleuria, Agaricus, Boletus, Mycena, Cortinarius, Nolanea and Ganoderma.
\end{abstract}

Copy Right, IJAR, 2017,. All rights reserved.

\section{Introduction:-}

The word "mushroom" that have a stem (stipe), a cap (pileus), and gills (lamellae, singular lamella) or spores on the underside of the cap. "Mushroom" describes both the fleshy fruiting bodies of some Ascomycota and the woody or leathery fruiting bodies of some Basidiomycota, depending upon the context of the word. They vary much in shape, size and color; some of them are edible and some proven to be poisonous (referred to as toadstools). There are many edible i.e. volvarias, polypore and tubers fungi that used ethno botanical food by the tribal of forest regions of India, Bangladesh and Nepal.

Humans have consumed fungi for sustenance, medicine, and culinary delight since ancient times. Some fungi are purposely cultivated, but most edible fungi are gathered from the wild. The Romans and Greeks treated mushrooms as a special kind of food (Miles and Chang, 2004), There are also reports of the use of fungi by the indigenous cultures of South America (Henkel, 2004), Africa (Van Dijk, 2003), Australia (Trappe, 2009), and Asia (Yun, 1997).

Mushrooms are seasonal fungi, which occupy additional lists appeared in between culminating with the diverse niches in nature in the forest ecosystem. Their habitat and climate are major factors that indicate their biodiversity. Characterized by different morphological traits i.e. shape of cap, cap edge, size of fructification, stipe length (cm), pileus length, margin of fruit body, color of fruit body, gills, scale, annulus, volva and spore print etc. Results 
indicate that all the species of mushrooms shows great diversity in their morphological characters (Srivastavaet al., 2010). Spore of fungi are vital for the dispersal of the species. The size of spore is on average 5 to $15 \mu \mathrm{m}$ (thousandth of a milimeter). The color, structure or ornamentation of spore varying from species to species of Mushrooms (Svrcek, 2000).

Mushroom is one of the promising concepts for crop diversification in Bangladesh as well as the whole world. The species diversity of fungi and their natural beauty occupy prime place in the biological world. The scope is limitless and this is high time to survey, collect, conserve, record and identifying the biodiversity, habitat and morphology in general and fungal diversity in particular as no one knows when and how some these valuable forms might be lost for forever. With the view in mind, the research work was undertaken to study the biodiversity and habitat of mushroom grown in different forest regions of Bangladesh and to study the morphological characteristics of different mushrooms identified in selected districts of Bangladesh.

\section{Materials and methods:-}

Experiment was conducted at the Department of Plant Pathology (DPP), Sher-e-Bangla Agricultural University (SAU), Dhaka. Samples were collected from different natural forest zones of Bangladesh (Table 1). The samples were collected during the period from June to September, 2013 and June to September, 2014. More than 85\% annual rainfall, mean daily temperature ranges between 29 to $31^{\circ} \mathrm{C}$ and relative humidity more than $80 \%$ is received during the monsoon period (June to September). Soil $\mathrm{P}^{\mathrm{H}}$ ranges in between 6 to 6.5. Maximum Mushrooms grown on natural humus of the forest and maximum hard caped mushrooms such as Ganoderma grown on bark of tree or dead plant as parasite or saprophytes. During samples collection a systematic sampling procedure was followed. A predesigned collection and data analysis procedures were used to collect the information on level of knowledge on biodiversity, habitat and morphology of Mushrooms.

Table 1:-Survey area of leaved, deciduous and mixed forest of Bangladesh

\begin{tabular}{|l|l|l|l|l|l|}
\hline \multirow{2}{*}{$\begin{array}{l}\text { Number } \\
\text { District(s) }\end{array}$} & \multicolumn{5}{l}{ Sample Upazilla (s) } \\
\cline { 2 - 6 } & \multicolumn{2}{|l|}{ Name of Sample Upazilla(s) } & $\begin{array}{l}\text { Number (s) } \\
\text { of Upazilla }\end{array}$ \\
\hline Barisal & Sadar & Goronodi & - & - & 2 \\
\hline Borguna & Sadar & Betagi & Bamna & Pathorghata & 4 \\
\hline Patuakhali & Sadar & Bauphal & Dashmina & Golachipa & 4 \\
\hline Perojpur & Sadar & Bhandaria & - & - & 2 \\
\hline Jhalokathi & Sadar & Nolchity & - & - & 2 \\
\hline Bandorban & Hafejghona & - & - & - & 1 \\
\hline Dhaka & Mirpur & - & - & - & 1 \\
\hline Gazipur & Sadar & - & - & - & 1 \\
\hline Tangail & Modhupur & - & - & - & 1 \\
\hline \multicolumn{1}{|l|}{9} & & & & \\
\hline
\end{tabular}

\section{Mushroom collection and processing:-}

Freshly harvested mushroom was washed by water for removing debris. Fleshy mushroom is highly perishable as it is susceptible to deterioration by the enzyme and microorganism (Deshmukh, 2004). During the analysis period some precautions before processing of mushroom (Pathak et al., 1998). Short term preservation were followed and another is long term preservation on the basis of study purpose and structure of the mushroom.

Collected mushrooms were dried by using sun heat (Sun dry) when collected mushroom from remote area where electricity was not available. But most of the collected samples were dried by using electrical air flow drier. Samples were stored in Ziploc poly bag during research period with Silica gel at the rate of $10 \%$ of dry basis for further study.

\section{Habitat and diversity analysis:-}

The types of forests were leaved, deciduous and mixed. The surrounding environmental temperature, relative humidity, soil $\mathrm{P}^{\mathrm{H}}$, moisture condition, vegetation were recorded for biodiversity of mushrooms (Aunget al., 2008). Soil $\mathrm{P}^{\mathrm{H}}$ and soil moisture were measured by $\mathrm{P}^{\mathrm{H}}$ meter and air temperature by thermometer during collection period 
(Haksworth, 2004). The frequency and density of different species has been determined by the following formulas (Zoberiet al., 1973).

Frequency of fungal species $(\%)=\frac{\text { Number of site in which the species is present }}{\text { Total number of sites }}$
Density $(\%)=\frac{\text { Total number of individual of a particular species }}{\text { Total number of species }}$

Procedure of morphological and taxonomic characterization:-

The cap (pileus) is borne on a stalk (Badalyan et al., 2004). It can be various shapes. The most familiar being hemispherical or convex, depressed, offset, umbonate, umblicate, infundibiliform with many of this becoming flat as it matures (Svrcek, 2000).

Cap edge may be grooved, plicate, and split shape. Spores of mushrooms are vital for the dispersal of the species. The form, color, and structure are varying from species to species (Svrcek, 2000). Regular survey and morphological characterization such as the fructification, carpophores shape, umbo, scale, the gills, color, gills edges, stipe length, width, color, shape, type of vail, annuls (Position), volva etc. were measured in fresh form during collection period (Srivastava et al., 2010). Qualitative characters such as color, shape, and presence of hymenia were evaluated by eye estimation while texture was determined by feeling the back and top surfaces using fingers.

Most of the morphological data were recorded during collection period when in fresh form. For microscopic characters, free hand transverse sections (approximately $0.1 \mathrm{~mm}$ ) thick were made from rehydrated basidiocarps observed the sections with a standard light microscope. There are different types of color and spore ornamentation such as globose or subglobose, cylindrical, fusiform, filiform, angular, echinulate, verrucose, tuberculate, obtusely fusiform, ovoid and ellipsoid etc. (Svrcek, 2000). Spore size was also measured.

The taxonomy has been suggested on the basis of macro and microscopic characteristic following available literatures (Zoberi, 1973 and Alexopolous et al., 1996) and identification the species based on identification key of Ahmad (1995) and Grimes (1994).

\section{Results:-}

A survey was conducted on biodiversity, habitat and morphology of mushrooms grown in eighteen natural forest zones under nine districts viz. Barisal, Borguna, Patuakhali, Perojpur, Jhalokathi, Bandorban, Dhaka, Gazipur and Tangail. A total of one hundred seventeen mushroom samples were collected and identified to twenty species under ten families. Their biodiversity, habitat and morphology of the collected mushrooms were recorded and described.

\subsection{Agaricus sp.}

\section{Biodiversity and habitat:-}

A total nine number of Agaricus mushrooms were found during collection. Agaricus sp. was found in Modhupur, Dhaka, Dashmina and Pathorghata. The frequency of its presence was $22.22 \%$ and the density was $40 \%$. The mushroom was found on the root zone of Leucaena leucocephala. Forest type was leaved. Soil moisture was 6.5, soil $\mathrm{P}^{\mathrm{H}}$ was 7.0 and soil type was sandy loam. Average temperature was recored $30{ }^{\circ} \mathrm{C}$ during collection.

\section{Morphology:-}

Fructification size was $12 \times 4 \mathrm{~cm}$. The color of pileus (cap) was brownish and the shape of cap was convex and umbonate. The cap edge was grooved and split. Brownish color scale was found on the cap. Beneath the cap hymenophores were present. Regular shaped gills (lamellae) were present underside of the cap of Agaricussp. The color of gills was deep brown. Color of stipe was whitish. The length and width of stipe was $5 \mathrm{~cm}$ and $0.7 \mathrm{~cm}$. Ring or anal was present on the stipe and volva was present on the lower part of the stipe in some Agaricussp. Spore color was whitish, spore ornamentation was ovoid with a coarsely round cerculate surface and spore size was $12 \times 8 \mu \mathrm{m}$ (Plate 1). 


\subsection{Amanita bisporigera}

Biodiversity and habitat:-

Amanita bisporigera was found in Modhupur and Pathorghata in natural forest zones of Bangladesh. The frequency of its presence was $11.11 \%$ and the density was $20 \%$. A total ten number of mushrooms of Amanita were found during collection.The mushroom Amanita bisporigera were found on the root zone of Dalbergiasissoo, on leaved forest zones.Soil moisture was 7 and $\mathrm{P}^{\mathrm{H}}$ was 6.5 , soil type was clay and the average recorded temperature was 29.5 ${ }^{0} \mathrm{C}$.

\section{Morphology:-}

Fructification size was $9 \times 3 \mathrm{~cm}$. The color of pileus (cap) was white and the shape of cap was convex. The cap edge was flat or grooved. Whitish scale was found on the cap. Beneath the cap hymenophores were present. Regular shaped gills (lamellae) were present underside of the cap of Amanita bisporigera. The color of gills was creamy white. Color of stipe was whitish. The length and width of stipe was 7-8 cm and $2.5 \mathrm{~cm}$. Ring or anal was present on the stipe and volva was absent on the lower part of the stipe in some Amanita bisporigera. Spore color was white, spore ornamentation was hyaline and spore size was $6 \times 5 \mu \mathrm{m}$ (Plate 1 ).

\subsection{Aleuria sp.}

\section{Biodiversity and habitat:-}

Aleuria aurantia was found in Perojpur and Borguna. One species of Aleuria was recorded and that was Aleuria aurantia. A total eight number of Aleuria aurantia mushrooms were found during collection. The frequency of its presence was $11.11 \%$ and the density was $40 \%$. The mushroom was found on the natural humus of the forest. Forest type was Deciduous. Soil moisture was 7 , soilP $\mathrm{H}^{\mathrm{H}}$ was 7.0 and soil type was clay loam. Average temperature was recored $29.5^{\circ} \mathrm{C}$ during collection.

\section{Morphology:-}

Fructification size was $7.9 \times 3 \mathrm{~cm}$. The color of pileus (cap) was orange peel. The shape of cap was convex and flat. The cap edge was grooved. Yellow color scale was found on the cap. Beneath the cap hymenophores were present. Regular shaped gills (lamellae) were present underside of the cap of Aleuria aurantia. The color of gills was white to light yellow. Color of stipe was greenish white. The length and width of stipe was $3.5 \mathrm{~cm}$ and $0.8 \mathrm{~cm}$. Ring or anal was absent on the stipe and volva was absent on the lower part of the stipe in Aleuria aurantia. Spore print was white, spore ornamentation was ellipsoidal and spore size was $24 \times 9 \mu \mathrm{m}$ (Plate 1).

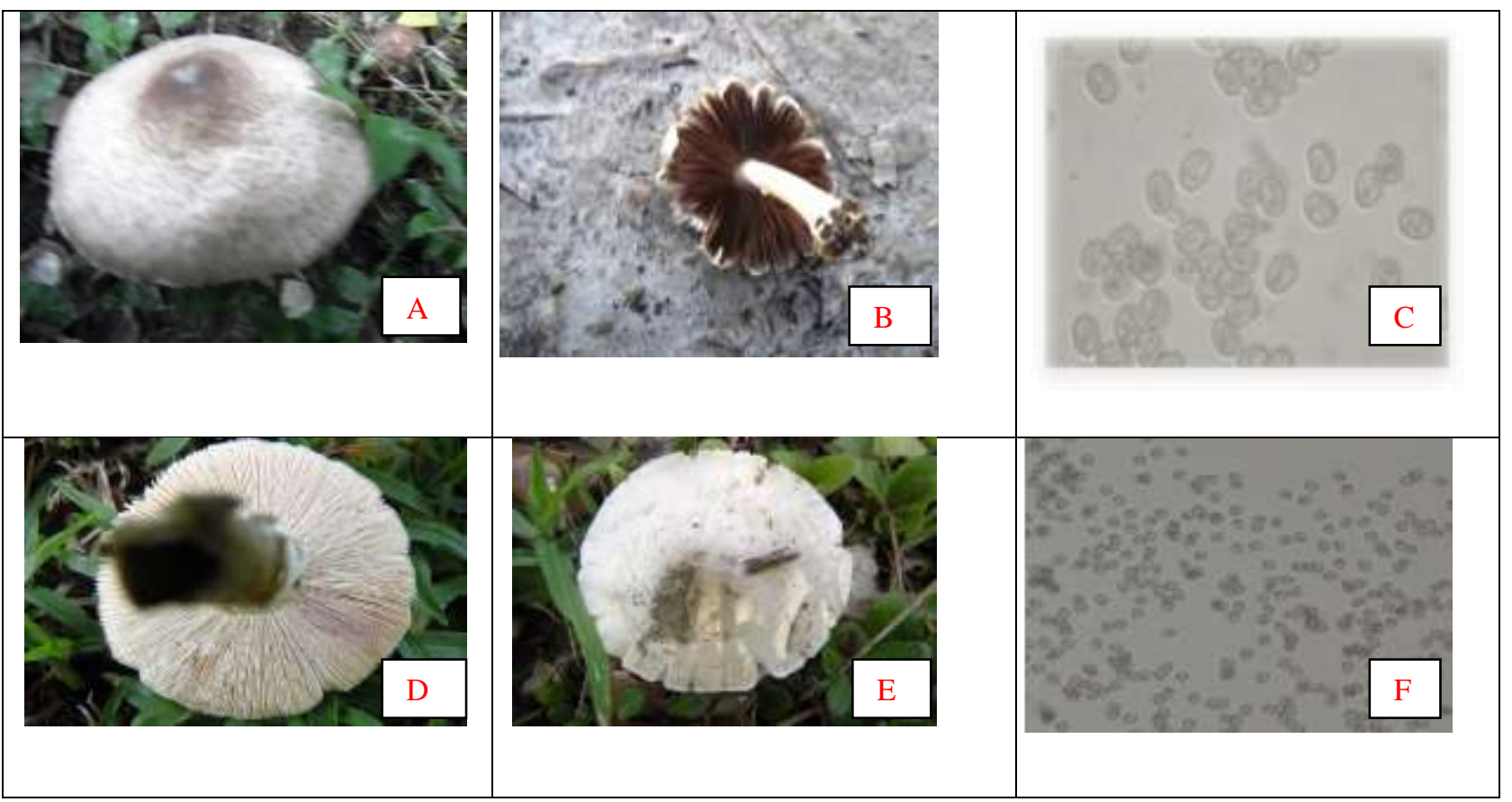




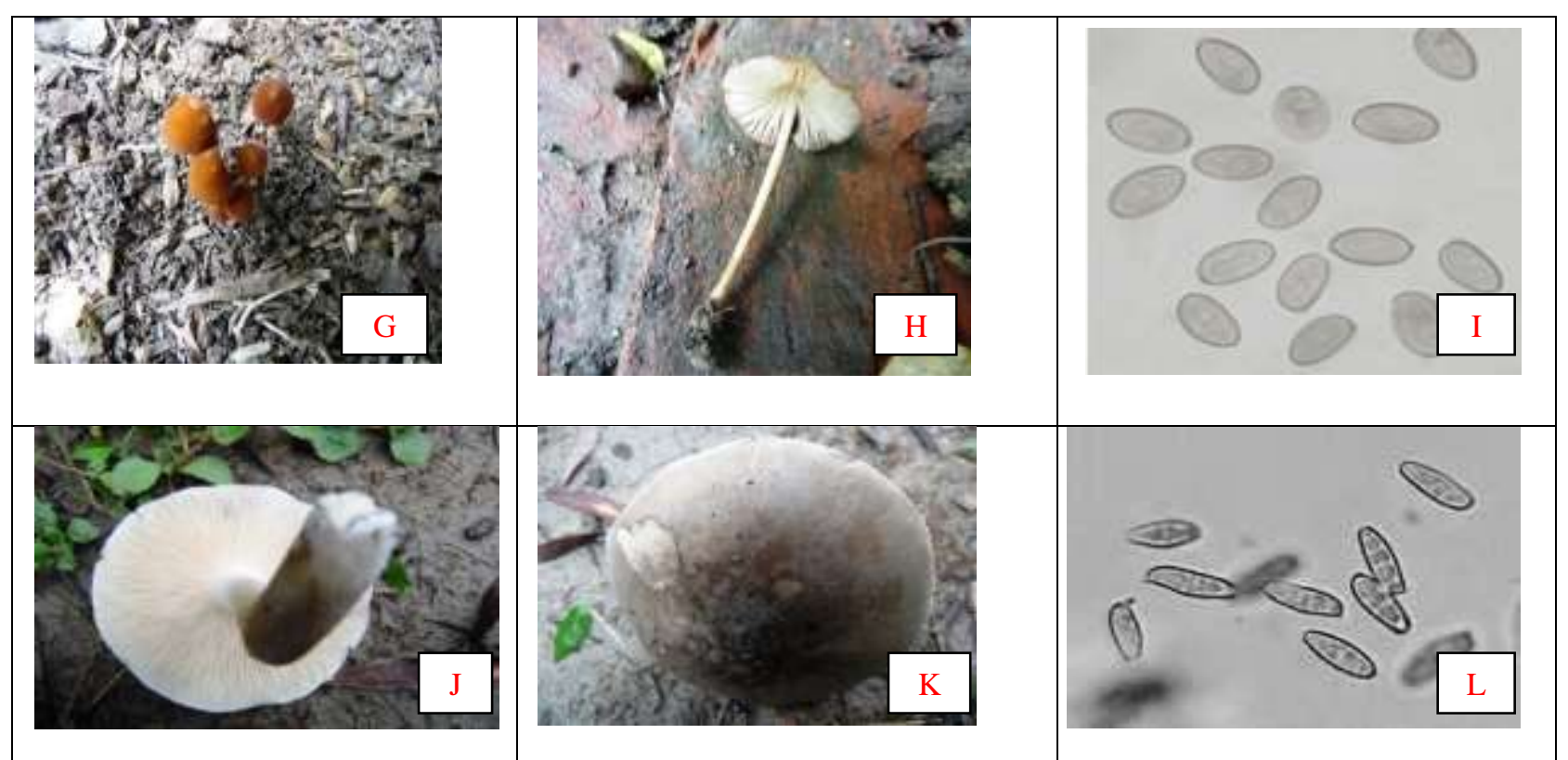

Plate 1. Photographs of Agaricus sp: umbonate shape cap (A), grooved cap edge (B)and ovoid spore (C);Photographs of Amanita bisporigera: Convex cap (D), flat cap (E), hyaline spore (F); Photographs of Aleuria aurantia: Convex cap $(\mathrm{G})$, cap edge grooved(H) ellipsoidal spore (I); Photographs of Boletus subvelutipes: gill (J), convex cap $(\mathrm{K})$ and obtusely fusiform spore (L)

\subsection{Boletus sp.}

Biodiversity and habitat:-

One species of Boletus was recorded in Modhupur and Patuakhali. and that was Boletus subvelutipes. Only one number of Boletus subvelutipes was found. The frequency of its presence was $11.11 \%$ and the density was $5 \%$. This mushroom was found on the root zone of Acacia auriculiformis. Forest type was mixed. Soil moisture was 7 , soil $\mathrm{P}^{\mathrm{H}}$ was 6.7 and soil type was clay loam. Average recorded temperature was $30^{\circ} \mathrm{C}$.

\section{Morphology:-}

Fructification size was 8-13x4-7 cm. The color of pileus (cap) was ash. The shape of cap was convex. The cap edge was grooved or plicate. Ash color scale was found on the cap. Regular shaped gills (lamellae) were present underside of the cap of Boletus subvelutipes. The color of gills was white. Color of stipe was ash to white. The length and width of stipe was $6 \mathrm{~cm}$ and $1 \mathrm{~cm}$. Ring or anal was absent on the stipe and volva was absent on the lower part of the stipe in Boletus subvelutipes. Spore color was white, spore ornamentation was obtusely fusiform with transverse septa and spore size was $14 \times 7.5 \mu \mathrm{m}$ (Plate 1).

\subsection{Genus: Callistosporium sp. \\ Biodiversity and habitat:-}

A survey was conducted in Modhupur, Patuakhali and Perojpur. One species of Callistosporiumwas recorded and the species was unidentified. Only one number of Callistosporium was found. The frequency of its presence was $16.67 \%$ and the density was 5\%. This mushroom was found on the root zones of Bambusa vulgaris. Forest type was mixed. Soil moisture was 6 , soil $\mathrm{P}^{\mathrm{H}}$ was 6 to 6.5 and soil type was clay loam. Average recorded temperature was 30 ${ }^{0} \mathrm{C}$.

\section{Morphology:-}

Fructification size was $8 \times 2.5 \mathrm{~cm}$. The color of pileus (cap) was yellowish. The shape of cap was ovate or convex. The cap edge was plicate or grooved. Yellowish scale was found on the cap. Beneath the cap hymenophores were present. Regular shaped gills (lamellae) were present underside of the cap of Callistosporiumsp. The color of gills was yellowish. Color of stipe was yellow. The length and width of stipe was $5 \mathrm{~cm}$ and $0.4-0.5 \mathrm{~cm}$. Ring or anal was absent on the stipe volva was absent on the lower part of the stipe in some Callistosporiumsp. Spore color was brown, spore ornamentation was globose and spore size was $7 \times 5 \mu \mathrm{m}$ (Plate 2 ). 
Table 2:- Taxonomy of collected macrofungi

\begin{tabular}{|l|l|l|l|l|l|l|}
\hline Kingdom & Phylum & Class & Order & Family & Genus & Species \\
\hline Fungi & Basidiomycota & Agaricomycetes & Agaricales & Agaricaceae & Agaricus & Agaricussp. \\
\hline Fungi & Basidiomycota & Agaricomycetes & Agaricales & Amanitaceae & Amanita & A. bisporigera \\
\hline Fungi & Ascomycota & Pezizomycetes & Pezizales & Pyronemataceae & Aleuria & A. aurantia \\
\hline Fungi & Basidiomycota & Agaricomycetes & Boletales & Boletaceae & Boletus & B. subvelatipes \\
\hline Fungi & Basidiomycota & Agaricomycetes & Agaricales & Tricholomataceae & Callistosporium & Callistosporiumsp. \\
\hline Fungi & Basidiomycota & Agaricomycetes & Russulales & Russulaceae & Russula & R. crustosa \\
\hline Fungi & Basidiomycota & Agaricomycetes & Agaricales & Cortinariaceae & Cortinarius & C. corrugatus \\
\hline Fungi & Basidiomycota & Agaricomycetes & Agaricales & Marasmiaceae & Gymnopus & Gymnopussp. \\
\hline Fungi & Basidiomycota & Agaricomycetes & Agaricales & Mycenaceae & Mycena & M. epipterygia \\
\hline Fungi & Basidiomycota & Agaricomycetes & Agaricales & Entolomataceae & Nolanea & Nolanea \\
\hline Fungi & Basidiomycota & Agaricomycetes & Polyporales & Ganodermataceae & Ganoderma & G. lucidum \\
\hline
\end{tabular}
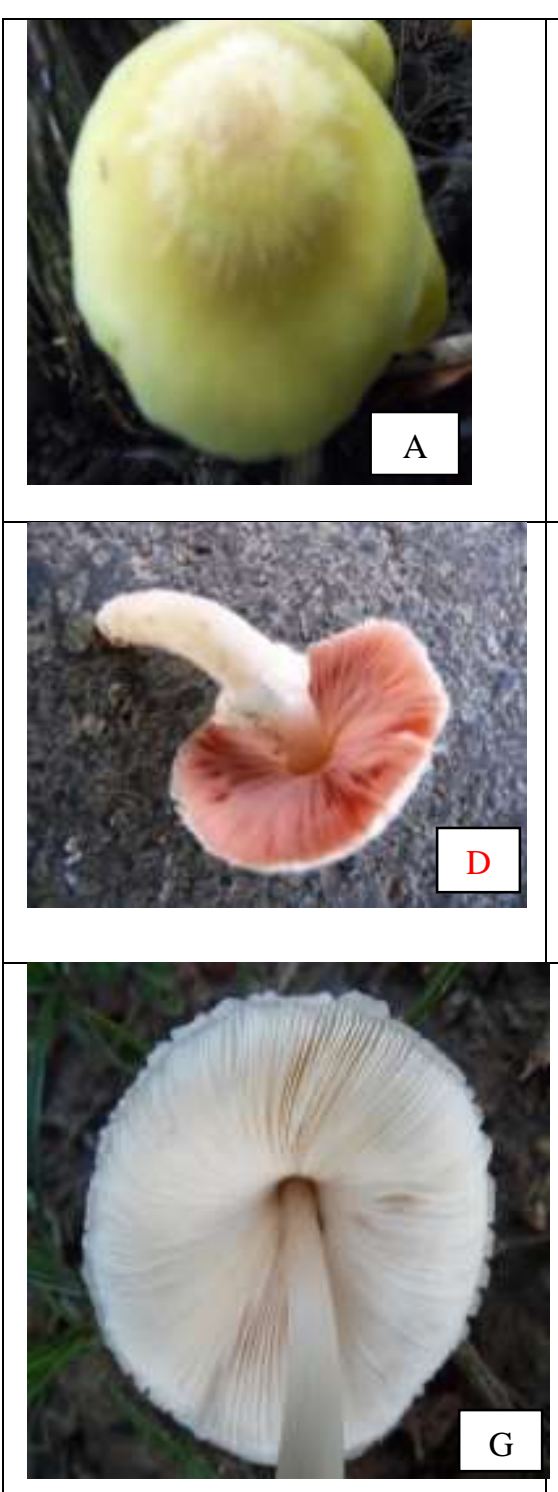
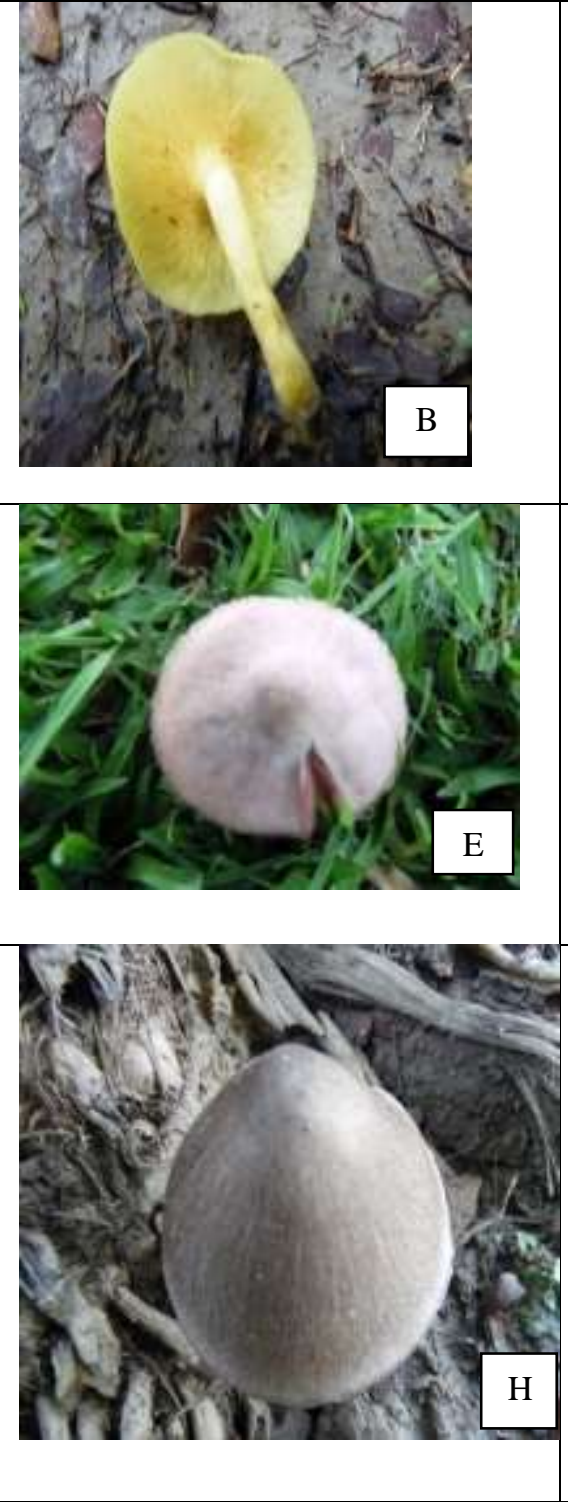
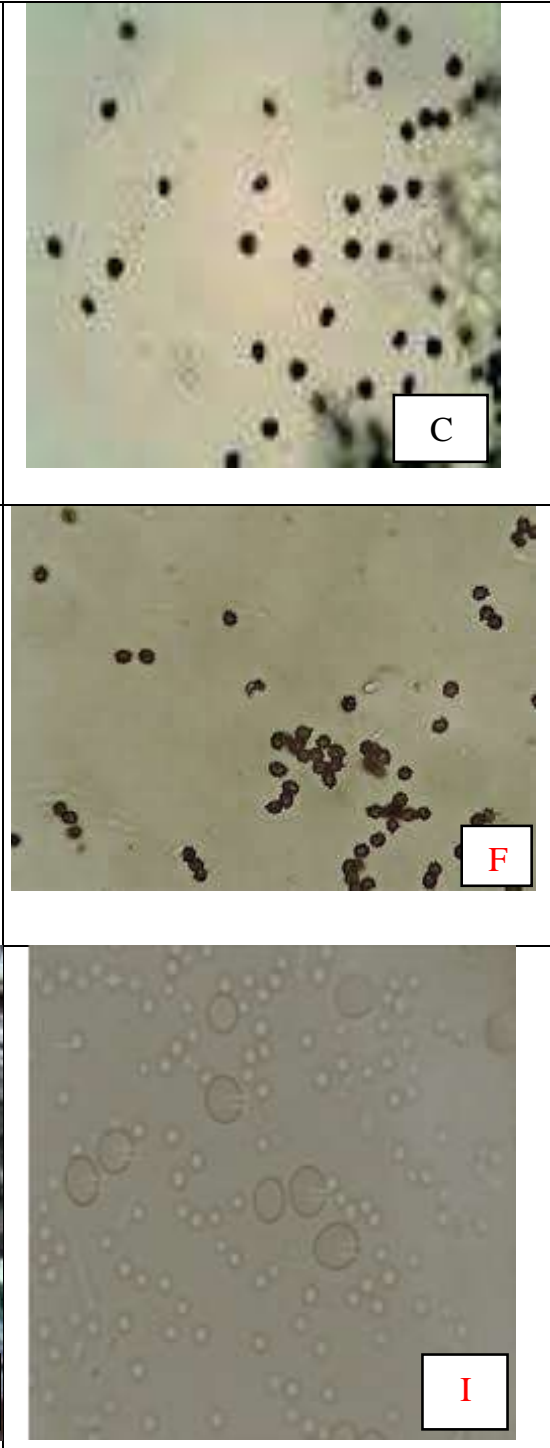


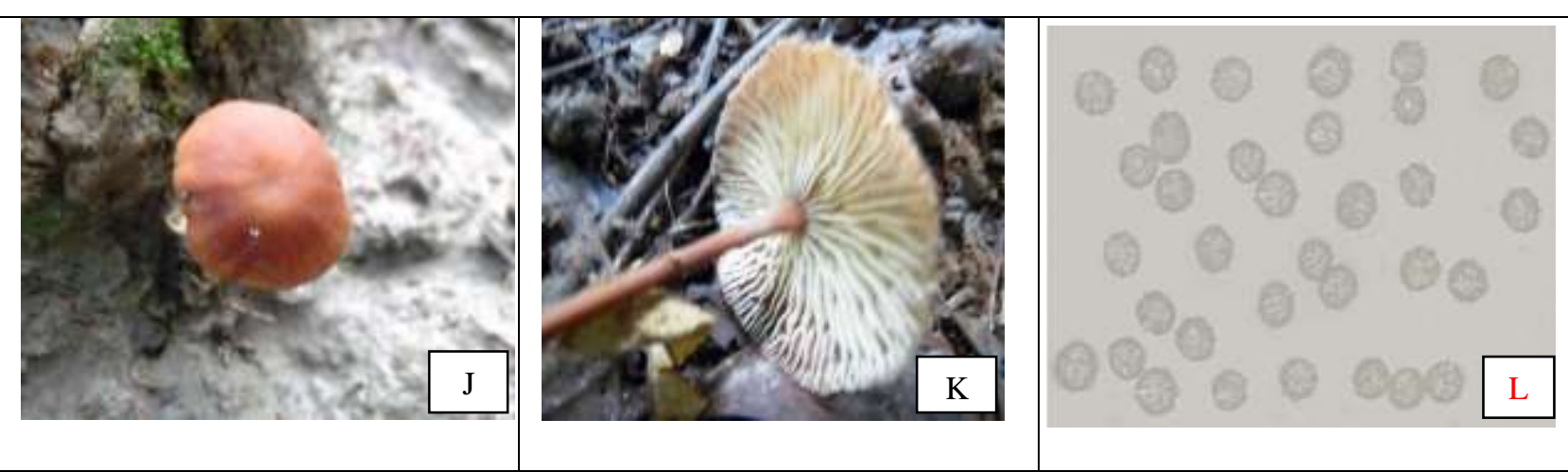

Plate 2:-Photographs of Callistosporium sp: Ovate shape cap, (A) grooved cap edge ( B), globose spore (C); Photographs of Russula crustosa: Umbonate cap (D), light brown gills (E), globose spore (F); Photographs of Cortinarius corrugatus: grooved cap edge and white gills (G), Ovate shape cap (H) oval shaped spore (I); Photographs of Gymnopus sp: Convex cap (J), hard gills (K) and echinulate spore (L).

\subsection{Genus: Russulasp.}

Biodiversity and habitat:-

A survey was conducted in Modhupur, Patuakhali and Pathorghata. One species of Russula was recorded and that was Russula crustosa. Five number of Russula were found during collection. Russula crustosa was found in Modhupur, Patuakhali and Pathorghata. The frequency of its presence was $16.67 \%$ and the density was $25 \%$. The mushroom was found on the root zone of Dalbergia sissoo. Forest type was mixed and leaved. Soil moisture was 7 , soil $\mathrm{P}^{\mathrm{H}}$ was 6 to 6.5 and soil type was clay loam. Average recorded temperature was $31^{0} \mathrm{C}$.

\section{Morphology:-}

Fructification size was $11 \times 3 \mathrm{~cm}$. The color of pileus (cap) was pink to white mixed and the shape was convex and umbonate. The cap edge was grooved and split. Pink color scale was found on the cap. Beneath the cap hymenophores were present. Regular shaped gills (lamellae) were present underside of the cap of Russula crustosa. The color of gills was creamy white. Color of stipe was white to light brown. The length and width of stipe was 3 $\mathrm{cm}$ and $1.4 \mathrm{~cm}$. Ring or anal was present on the stipe and volva was absent on the lower part of the stipe in Russula crustosa. The color of spore was greenish, ornamentation was globose and spore size was $6 \times 4.5 \mu \mathrm{m}$ (Plate 2 ).

\subsection{Genus: Cortinarius sp. \\ Biodiversity and habitat:-}

A survey was conducted in Pathorghata and Golachipa. One species of Cortinarius was recorded and that was Cortinarius corrugatus. Only one number of Cortinarius was found during collection. Cortinarius corrugatus was found in Pathorghata and Golachipa. The frequency of its presence was $11.11 \%$ and the density was 5\%. The mushroom was found on the on the root zone of Musa paradisiaca. Forest type was mixed. Soil moisture was 6.5, soil $\mathrm{P}^{\mathrm{H}}$ was 6.2 and soil type was clay. Average recorded temperature was $29{ }^{0} \mathrm{C}$.

\section{Morphology:-}

Fructification size was $12 \times 3 \mathrm{~cm}$. The color of pileus (cap) was ash color. The shape of cap was ovate. The cap edge was grooved. Ash color scale was found on the cap. Beneath the cap hymenophores were present. Regular shaped gills (lamellae) were present underside of the cap of Cortinarius corrugatus. The color of stipe was milky white. The length and width of stipe was $8 \mathrm{~cm}$ and $3 \mathrm{~cm}$ respectively. Gills were present and color of gills are milky white. Black ring or anal was present on the upper part of stipe and volva was absent on the lower part of stipe of Cortinarius corrugatus. The color of spore was white, ornamentation was round circle and size of spore was $6 \times 6 \mu \mathrm{m}$ (Plate 2).

\subsection{Genus: Gymnopussp. \\ Biodiversity and habitat:-}

A survey was conducted in Perojpur and Patuakhali. One species of Gymnopus was recorded and that was Gymnopus sp. Two number of Gymnopus were found during collection.Gymnopus sp. was found in Perojpur and Patuakhali. The frequency of its presence was $11.11 \%$ and the density was $10 \%$.The mushroom was found on the 
root zone of Swietenia macrophylla and on natural humus of forest. Forest type was deciduous. Soil moisture was 7 , soil $\mathrm{P}^{\mathrm{H}}$ was 6.2 and soil type was sandy loom and clay loom. Average recorded temperature was $30{ }^{\circ} \mathrm{C}$.

\section{Morphology:-}

Fructification size was $4-5 \times 2-3 \mathrm{~cm}$. The color of pileus (cap) was brick red. The shape of cap was convex. The cap edge was grooved. Scale was not found on the cap. Beneath the cap hymenophores were present. Regular shaped gills (lamellae) were present underside of the cap of Gymnopus sp. The color of stipe was light purple. The length and width of stipe was $0.8-2 \mathrm{~cm}$ and $0.3-0.6 \mathrm{~cm}$. Gills were present and color of gills are brown to white. Ring or anal was abesent on the upper part of stipe and volva was absent on the lower part of stipe of Gymnopus sp. The color of spore print was greenish, ornamentation was echinulate and size of spore was $11.5 \times 8 \mu \mathrm{m}$ (Plate 2 ).

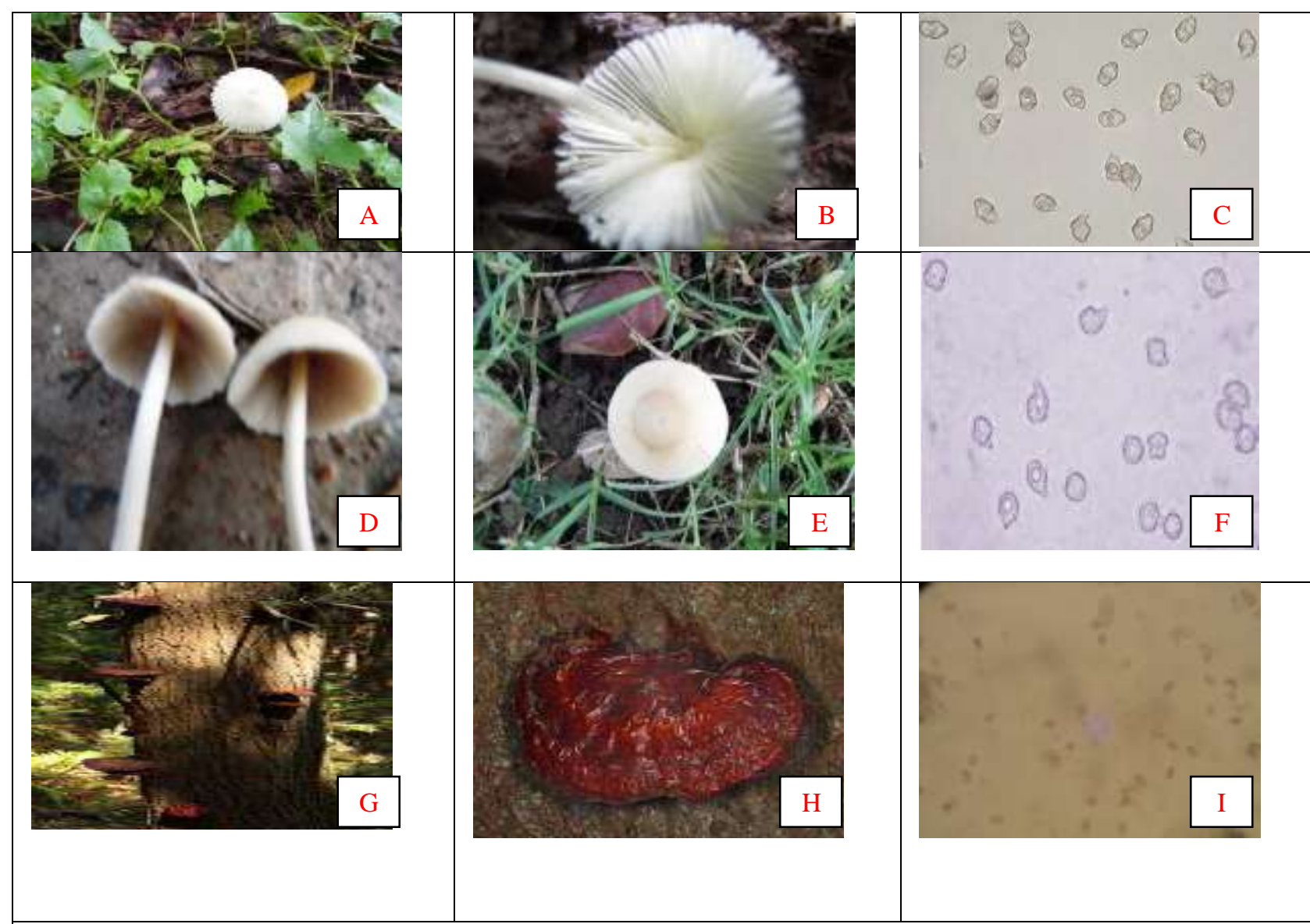

Plate 3:-Photographs of Mycena epipterygia: Umbonate cap (A), white gills (B), tuberculate spore (C); Photographs of Nolanea strictia: Brown gills (D), Umbonate cap (E), violet color globose and subglobose spore (F); Photographs of Ganoderma lucidumm; Fruiting body with host (G), A single fruit body (H) and spore (I).

\subsection{Mycenasp.}

\section{Biodiversity and habitat:-}

A survey was conducted in Patuakhali. One species of Mycena was recorded and that was Mycena epipterygia. Six number of Mycena were found during collection. Mycena epipterygia was found in Patuakhali. The frequency of its presence was $5.56 \%$ and the density was $30 \%$. The mushroom was found on the moist soil of the forest. Forest type was leaved. Soil moisture was 8 , soil $\mathrm{P}^{\mathrm{H}}$ was 6 and soil type was clay. Average recorded temperature was $30{ }^{\circ} \mathrm{C}$.

\section{Morphology:-}

Fructification size was $6 \times 2 \mathrm{~cm}$. The color of pileus (cap) was fleshy and whitish. The shape of cap was umbonate. The cap edge was split. Fleshy and white scale was found on the cap. Beneath the cap hymenophores were present. Regular shaped gills (lamellae) were present underside of the cap of Mycena epipterygia. The color of stipe was white. The length and width of stipe was $9-10 \mathrm{~cm}$ and $0.5 \mathrm{~cm}$. Gills were present and color of gills are white to light 
yellow. Ring or anal was abesent on the upper part of the stipe and volva was absent on the lower part of the stipe of Mycena epipterygia. The color of spore was ash, ornamentation was tuberculate and size of spore was $13 \times 10 \mu \mathrm{m}$ (Plate 3).

\subsection{Genus: Nolanea sp.}

Biodiversity and habitat:-

A survey was conducted in Pathorghata. One species of Nolanea was recorded and that was Nolaneastrictia. Seventeen number of Nolanea were recorded during collection. Nolanea strictia was found in Pathorghata. The frequency of its presence was $5.56 \%$ and the density was $85 \%$. The mushroom was found on the natural humus of the forest. Forest type was mixed. Soil moisture was 7 , soil $\mathrm{P}^{\mathrm{H}}$ was 6.5 and soil type was sandy. Average recorded temperature was $30^{\circ} \mathrm{C}$.

\section{Morphology:-}

Fructification size was $11 \times 3.8 \mathrm{~cm}$. The color of pileus (cap) was fleshy and creamy. The shape of cap was umbonate. The cap edge was grooved. Fleshy and creamy scale was found on the cap. Beneath the cap hymenophores were present. Regular shaped gills (lamellae) were present underside of the cap of Nolanea strictia. The color of stipe was white. The length and width of stipe was $3.5-6 \mathrm{~cm}$ and $0.6-1.5 \mathrm{~cm}$. Gills were present and color of gills are brown to white. Ring or anal was abesent on the upper part of the stipe and volva was absent on the lower part of the stipe of Nolanea strictia. Spore color was light violet, ornamentation was globose and subglobose. Spore size was $12 \times 9 \mu \mathrm{m}$ (Plate 3 ).

\subsection{Ganoderma sp.}

\section{Biodiversity and habitat:-}

A survey was conducted in Modhupur, Patuakhali, Perojpur, Bandorban, Borguna, Pathorghata, Jhalokathi and Dhaka. Three species of Ganoderma were recorded viz. Ganoderma lucidum, Ganoderma applanatum and Ganoderma tsuage. A total thirty eight number of Ganoderma were found during collection. Ganoderma lucidum was found in Modhupur, Patuakhali, Perojpur, Bandorban and Borguna. The frequency of its presence was 27.78\% and the density was 50\%.Ganoderma applanatum was found in Modhupur, Dhaka, Perojpur, and Bandorban. The frequency of its presence was $22.22 \%$ and the density was $45 \%$.Ganoderma tsuage was found in Modhupur, Patuakhali, Dhaka, Jhalokathi, Borguna and Pathorghata. The frequency of its presence was $33.33 \%$ and the density was $95 \%$. The mushrooms were found on the bark of tree and on dead plat. Forest type was mixed for all three specise of Ganoderma. Average soil moisture was 4-6 for all three specise of Ganoderma. Average soil $\mathrm{P}^{\mathrm{H}}$ was 6 to 6.5 for all three specise of Ganoderma. Soil type was clay loam. Average recorded temperature was $30{ }^{\circ} \mathrm{C}$ for three species viz. Ganoderm alucidum, Ganoderma applanatum and Ganoderma tsuage.

\section{Morphology:- \\ a. Ganoderma lucidum}

Fructification size was $20-25 \times 8-10 \mathrm{~cm}$. The color of pileus (cap) was red. The shape of cap was hard and flat. The cap edge was undulating. Scale was not found on the cap. Beneath the cap hymenophores were not present. Regular shaped gills (lamellae) were not present underside of the cap of Ganoderma lucidum. Pseudostem present under the cap. Ring and volva was absent (Plate 3).

\section{Discussion:-}

For the study of biodiversity, habitat and morphology of mushroom a survey was conducted in 18 upazila of selected 9 districts named Barisal, Patuakhali, Perojpur, Jhalokathi, Borguna, Tangail, Dhaka, Gazipur and Bandorban . After morphological study in both field and laboratory and spore ornamentation under microscope 20 different species were found and these were Agaricus sp., Amanita hemibapha, Amanita bisporigera, Amanita rubescens, Aleuria aurantia, Boletus subvelutipes, Callistosporium sp., Russula crustosa, Cortinarius corrugatus, Gymnopus sp., Mycena epipterygia, Nolaneastrictia, Ganoderma lucidum, Ganoderma apphannatum, Ganoderma tsuage, etc.

Agaricus sp. was found in Modhupur, Dhaka, Dashmina and Pathorghata. The frequency of its presence was 22.22\% and the density was 40\%. Another species,Agaricussilvicolawas found in Patuakhali, Barisal, Jhalokhathi where the frequency and the density was $18.75 \%$ and $11.62 \%$ respectively (Rashid et al, 2016). An investigation was conducted in the mangrove forest regions of Bangladesh and six species of Agaricus were identified (Das et. al, 2016).

A total ten number Amanita bisporigera was found in Modhupur and Pathorghata in natural forest zones of Bangladesh on the root zone of Dalbergia sissoo, on leaved forest zones. The frequency of its presence was $11.11 \%$ 
and the density was $20 \%$. Three species of Amanita were also reported in Pathorghata of Borguna districts in the southern region with a frequency and density of $6.25 \%$ and $9.30 \%$, respectively in an association with Dalbergia sissoo tree (Rashid et al, 2016). Also found in forest of northern Thailand (Lee et al., 2007). Amanita cinereovelatawas first identified from Sal forest of Bangladesh (Hosen et al, 2016). The same species was also reported in Switzerland (Breitenbach, 1995), California (Desjardin et al, 2015; Thiers, 1982) and North America . (Jenkins,1986). This genus was also reported from Bangladesh (Rumainul et al, 2016) and India (Dwivediet al, 2012).

Aleuriaaurantia was found in Perojpur and Borguna deciduous forest on the natural humus. Frequency of its presence was $11.11 \%$ and the density was $40 \%$ on the natural humus of the forest.Karl Wilhelm Gottlieb Leopold Fuckel placed it the genus Aleuria in 1870. Aleuria fungus was also found on bare clay or disturbed soil throughout in North America and Europe. It was also noticed from south of Chile. Aleuriaaurantia fruits mainly in late summer and autumn.

Russulacrustosa was found in Modhupur, Patuakhali and Pathorghata. The frequency of its presence was $16.67 \%$ and the density was $25 \%$.Russulanobiliswas also found with $5 \%$ density on humus, in an association with Kalmegh (Andrographispaniculata) in National Botanical Garden, Dhaka (Rubinaet al.,2017).

Mycenaepipterygia was found in Patuakhali on the moist soil of the forest. The frequency of its presence was 5.56\% and the density was 30\%. Amanita and Russula were also reported in India (Dwividiet al,2012; Thiribhuvanamala et al, 2011;Mohanan,2011). Amanita muscaria was also reported by Rumainul et al., 2015.The genus Mycena was also reported in an association with Swietenia mahagonitree from the previous investigation of tropical deciduous forest region of Bangladesh and also from the Lagos State of Nigeria (Rumainulet al., 2015; Bankole and Adekunle, 2012). Mycena californiensis was also recorded by Rahman et al., 2016 with density $10.81 \%$ at South -west region of Bangladesh.

Cortinariuscorrugatus was found in Pathorghata and Golachipa on the root zone of Musa paradisiaca.having the frequency of its presence $11.11 \%$ and the density was 5\%. Cortinarius corrugates was identified in Sadar and Pathorghata sub-districts of Patuakhali and Barguna districts in southern region of Bangladesh with a frequency and density of $12.5 \%$ and16.7\%, accordingly (Rashid et al.2016). Cortinarius sp. was also found in North America and Europ (Breitenbach et al.,1995).

Boletus subvelutipes was recorded in Modhupur and the frequency of its presence was $11.11 \%$ and the density was $5 \%$. B. edulis is considered one of the safest wild mushrooms to pick for the table, as no poisonous species closely resemble it. Boletus edulis was first described in 1782 by the French botanist Pierre Bulliard and still bears its original name (Bulliard,1782). It is common in Europe-from northern Scandinavia, south to the extremities of Greece and Italy - and North America, where its southern range extends as far south as Mexico (Wang et al,1995) Boletus sp was reported in woodland park, Wasinghton in 2016. Boletellus mirabilis was recorded from Mount Rainier National Park, Lake 22, Granite Falls 0f Lake 22, Washington, USA in 2014, Boletus sp was also repoted in woodlwnd park, Wasinghton in 2016(Thiers \& A.H. Sm., 2016).

Gymnopus sp. was found in Perojpur and Patuakhali having of its presence was $11.11 \%$ and the density was $10 \%$ on the root zone of Swietenia macrophylla and on natural humus of forest. Gymnopus dryophilus was commonly found in temperate woodlands of Europe and North America and sometimes considered as a "weed" mushroom (Kuo, 2008). It is generally saprophytic, but occasionally also found on living wood or other broad-leaved trees or with conifers and it fruits from April to December (Collins, 1999).

Callistosporium sp. was recorded at Modhupur, Patuakhali and Perojpur having frequency $16.67 \%$ and density $5 \%$. Callistosporiumvinosobrunneum is saprotrophic fungus and was distributed in solitarily to scattered on the rotting wood of the flowering evergreen tree (Metrosiderospolymorpha) to the islands of Hawai'i and Kaua'i(Desjardin and Hemmes, 2011).

Seventeen number of Nolaneastrictia were recorded in Pathorghata on the natural humus of the forest. The frequency and the density of its presence was $5.56 \%$ and $85 \%$ respectively. Nolanea xylophila was reported from Britain, southern England and from Scotland, but it may be more common in parts of mainland Europe grows not on soil but on rotting (Paul et al.,2008). 
There are three species were collected during the investigation, viz-Ganoderma applanatum, Ganoderma tsugae and Ganoderma lucidum on the bark of tree and on dead plant, Ganoderma sp. Among the species, the highest frequency of Ganoderma tusagae was $33.33 \%$ and the density was $95 \%$.Ganoderma sp. was also identified from Rajshahi, Pabna, Jaipurhat and Dhaka district of the tropical moist deciduous forest region in Bangladesh (Rumainul et.al, 2015) and first found in 1905 by American mycologist named William Murrill (Murrill, 1905). This species was also reported in China (Wang, et al, 2012) and India (Ram, 2012). The species of Ganoderma was reported at the Mangrove forest and tropical moist deciduous forest regions of Bangladesh and India (Das and Aminuzzaman, 2017, Copper et al, 2011; Pushpa andPurushothama, 2012).Both of Ganoderma lucidum and Ganoderma appalantum were reported in India and Nigeria (Pushpa and Purushothama, 2012).

In the present study the fleshy mushrooms were mostly found on natural humus of the forest and hard woody mushroom such as Ganoderma grow on the bark of living tree as parasites or on the dead plant body as saprophytes. Mixed type forest is best for mushroom growth and development. Morphologically most of the fruiting body of mushrooms is white and there are also some yellow, orange, brown, and ash color mushroom. Cap shape mostly convex and cap edge grooved in most of the species. Stipe is present in most of the fleshy mushroom and most of Ganoderma and Polyporus species attached with bark of tree by means of pseudostem. White gills present underside of the cap or pileus that is hymenophores present all of the fleshy fungi which grow on soil or humus and hymenophores absent in most of the mushroom which attached with tree. The maximum frequency of occurrence was exhibited by Ganoderma tsuage (33.33\%) and the maximum density was recorded for Ganoderma tsuage (95\%). This informative study shows that the forest of Bangladesh is rich in mushroom diversity.

\section{Conclusion:-}

The present study provides a database on macro fungal diversity of Bangladeshi forest, along with their ecological preferences and utilization. As soil and climate situation of this region is very suitable for mushroom cultivation; Bangladesh has a huge prospect of mushroom cultivation. Through mushroom cultivation, it is possible to generate considerable employment opportunity, alleviate poverty, and reduce malnutrition to meet the required protein of Bangladeshi people. Even it is possible to earn a huge amount of foreign currency by exporting mushroom after meeting the domestic demand. So this is the high time to give emphasis on commercial production of mushrooms and taking wild edible mushroom under commercial cultivation to ensure food security in Bangladesh.

\section{Competing interests:-}

Authors have declared that no competing interests exist regarding the publication of this paper.

\section{References:-}

1. Ahmad, S. (1996). Development of mushroom varieties suitable for rural development in Bangladesh. A report of mushroom culture Centre, Department of Agriculture Extension, Saver, Dhaka.

2. Alexopolous, C. J., Mims, C. W., and Blackwell. (1996). Introductory Mycology and Sons Inc., Schultesfil.(Liliaceae). OT SistematikBotanikDergisi. 15 (2): 115-124.

3. Aung, O. M., Soytong, K. and Hyde, K.D. (2008). Diversity of entomopthogenic fungi in Rain Forests of China Mai province. Thailand, Fungal Diversity, 30: 15-22.

4. Badalyan, S. and Sakeyan, C. (2004). Morphological, physiological and growth characteristics of mycelia of several medicinal mushrooms (Aphyllophoromycetideae). International Journal of Medicinal Mushrooms 6(4): 347-360.

5. Bankole, P. O. and Adekunle, A. A. (2012). Studies on biodiversity of some mushrooms collected in Lagos State, Nigeria using biotechnological methods. Journal of Yeast and Fungal Research. 3(4):37-48

6. Breitenbach, J. and Kränzlin, F. (1995). Fungi of Switzerland. Volume 4: Agarics ( ${ }^{\text {nd }}$ Part). Entolomataceae, Pluteaceae, Amanitaceae, Agaricaceae, Coprinaceae, Strophariaceae. Verlag-Mykologia: Luzern,Switzerland. 368.

7. Bulliard, J. B. F. (1782). Herbier de la France. Vol 2 (in French). Paris, France: P.F. Didot. pp. 49-96.

8. Collins, H. (1999). RégisCourtecuisse : "Mushrooms of Britain \& Europe".

9. Cooper, R. M., Flood, J. and Rees, R. W. (2011). Ganodermaboninensein Oil Palm Plantations: Current thinking on epidemiology, resistance and pathology.The Planter 87(1024):515-526.

10. Das, K. and Aminuzzaman, F. M. (2017). Morphological and ecological characterization of xylotrophic fungi in mangrove forest regions of Bangladesh. Journal of Advances in Biology \& Biotechnology 11(4): 1-15. 
11. Deshmukh, S. K. (2004). Biodiversity of tropical basidiomycetes as sources of novel secondary metabolites. In Microbiology and Biotechnology for Sustainable Development (ed. P. C. Jain,), CBS Publishers and Distributors, New Delhi, pp: 120-140.

12. Desjardin, D. E. and Hemmes, D. E. (2011). "Agaricales of the Hawaiian Islands" Five new white-spored species from native montane wet forests". Mycologia. 103 (6): 1441-50.

13. Desjardin, D. E., Wood, M. G. and Stevens, F. A. (2015).vCalifornia mushrooms: The comprehensive identification guide. Timber Press: Portland. 560.

14. Dwivedi, S., Tiwari, M. K., Chauhan U. K. and Pandey, A. K. (2012). Biodiversity of mushrooms of amarkantak biosphere reserve forest of Central India. International Journal of Pharmacy \& Life Sciences 3(1): 1363-1367.

15. Farook ,V. A., Khan, S. S. and Manimohan, P. (2011). A checklist of agarics (gilled mushrooms) of Kerala State, India. Mycosphere. 4(1):97-131.

16. Grimes, G. L. (1994). Principle of Mushroom Identification in Hand Book of Mushroom Poisoning Diagnosis and Treatment (D.G. Spoerke and B.H. Rumackeds.) CRC, Press, London. 65-95.

17. Hawksworth, D. L. (2004). Fungal diversity and its implifications for genetic resource collections. Stud. Mycol. 50: 19.

18. Henkel, T., Aime, M., Chin, M. and Andrew, C. (2004). Edible mushrooms from Guyana. Mycologist 18:104111.

19. Horton, B. (2006).Mushrooms of Maatsuyker Island. The Tasmanian Naturalist. 128:11-22.

20. Hosen, M. I, Li, T. H. and Deng, W.Q. (2015). Amanita cinereovelata, a new species of Amanita section Lepidella from Bangladesh. Mycol Progress. 14:35.

21. Jenkins, D.T. (1986). Amanita of North America. Mad River Press: Eureka, CA.197.

22. Kau, F.L.M. and Mc. Clean, T. M. (2011). Persistence of basidiospores and sclerotia of ectomycorrhizal fungi and Morchella in soil. Mycologia 86:89-95.

23. Kuo, M. (2008). Gymnopusdryophilus at the Mushroom Expert.Com Web site).

24. Le, H.T., Nuytinck, J., Verbeken, A., Lumyong, S., Desjardin, D. (2007). Lactarius in northernspores and refractive hyphae in Amanita.Mycotaxon. 52:305-396.

25. Miles, P. Chang S.T. (2004). Mushrooms: cultivation, nutritional value, medicinal effect, and environmental impact. CRC, Boca Raton,

26. Mohanan, C. (2011) Macrofungi of Kerala, Kerala, India: Kerala Forest Research Institute.597.

27. Murrill ,W.A. (1905). Tomophagus for dendrophagus. Torreya. 5:197.

28. Pathak, V. N. and Yadav, N. (1998). Preservation and processing In: Mushroom Production and Processing Technology. Agrobios (India), Jodhpur, pp.134-151.

29. Paul, M. Kirk, Paul, F. Cannon, David, Minter, W. and Stalpers, J.A. (2008). Dictionary of the Fungi; Taxonomic history and synonym information. Kew's Checklist of the British \& Irish Basidiomycota.

30. Pushpa, H., and Purushothama, K.B. (2012). Biodiversity of mushrooms in and around Bangalore (karnataka), India. American-Eurasian J. Agric. \& Environ. Sci. 12(6):750-759.

31. Rahaman, M. F. M. Aminuzzaman, M. B. Hossain, S. N. Rashid and M. I. (2016).

32. Biodiversity, distribution and morphological characterization of mushrooms in the south western region of Bangladesh. International Journal of Advanced Research . 4(3): 60-79.

33. Ram R.C., PandeyV.N.and Singh, H.B.(2010).Morphological characterization of edible fleshy fungi from different forest regions.Indian J. Sci. Res.1(2):33-35.

34. Rashid, S.N. F. M., Aminuzzaman, M. R. Islam, M. Rahaman and M. I. Rumainul. (2016). Biodiversity and Distribution of wild Mushrooms in theSouthern Region of Bangladesh. Journal of Advances in Biology \& Biotechnology. 9(1): 1-25.

35. Rubina, H., Aminuzzaman, F. M., Chowdhury, M.S.M. and Das, K .(2017). Morphological Characterization of Macro Fungi Associated with Forest Tree of National Botanical Garden, Dhaka.Journal of Advances in Biology \& Biotechnology 11(4): 1-1

36. Rumainul, M. I., Aminuzzaman, F. M. and Chowdhury, M. S. M. (2015).Biodiversity and Morphological Characterization of Mushrooms at the Tropical Moist Deciduous Forest Region of Bangladesh. American Journal of Experimental Agriculture 8(4): 235-252.

37. Rumainul,M.I. and Aminuzzaman, F. M. (2016). Macro Fungi Biodiversity at the Central and Northern Biosphere Reserved Areas of Tropical Moist Deciduous Forest Region of Bangladesh. Journal of Agriculture and Ecology Research International. 5(4): 1-11

38. Srivastava, H. C. and Bano, j. (2010). Studies on the cultivation of Pleurotus species on paddy straw. Food Sci. 11:36-38. 
39. Svrcek M. (2000). A field Guide in color to Mushrooms. Leicester: Czech Republic,pp: 1-279.

40. Thiers \&Sm, A.H. (2016).Species List: Boletus and other tubed mushrooms of Washington State (236), Mushroom observer section 501(c)(3).

41. Thiers, H.D. (1982). The agaricales (Gilled Fungi) of California. 1. Amanitaceae. Mad RiverPress: Eureka, CA. 53.

42. Thiribhuvanamala, G., Prakasam, V., Chandrasekar G., Sakthivel, K., Veeralakshmi, S., Velazhahan R. and Kalaiselvi, G. (2011) Biodiversity, conservation and utilization of mushroom flora from the western ghats region of India. Proceedings of the $7^{\text {th }}$ International Conference on Mushroom Biology and Mushroom Products (ICMBMP7), Tamil Nadu, India. 155- 164.

43. Trappe, J., Molina, R., Luoma, D., Cazares, E., Pilz, D., Smith, J.E., Castellano, M., Miller, S.and Trappe, M. (2009). Diversity, ecology, and conservation of truffle fungi in forests of the Pacific northwest. PNW-GTR-772. FS United States Department of Agriculture. Pacific Northwest Research Station, Portland, OR, 194p.

44. Vandijk, H., Onguene, N.A., Kuyper, T.W. (2003). Knowledge and utilization of edible Mushrooms by local populations of the rain forest of south Cameroon. Ambio 32:19-23.

45. Wang, X.C., Xi, R.J., Li, Y., Wang, D.M., Yao, Y.J. (2012).The Species Identity of the widely cultivated Ganoderma, 'G. lucidum' (Lingzhi), in China. PLoSONE.7(7):e40857.

46. Wang, Y., Sinclair, L., Hall I.R. and Cole, A.L. (1995). "Boletus edulis sensulato: a new record for New Zealand" (PDF). New Zealand Journal of Crop and Horticultural Science. 23 (2): 227-31.

47. Yun, K., Namba, K. and Tajiri, A. (1997). Fruit body formation of Boletus reticulates in pure culture. Mycoscience 41: 189-191.

48. Zoberi, M.H. (1973). Some edible mushrooms from Nigeria. Nigerian Field 38:81-90. 